\title{
Counterargument to the West: Buddhist Logicians' Criticisms of Christianity and Republicanism in Meiji Japan
}

\author{
MORO Shigeki
}

MORO Shigeki is a professor at Hanazono University, Kyoto, Japan. He specializes in Yogācāra Buddhism and Buddhist logic in Japan and East Asia. He also studies Digital Humanities in the field of East Asian studies and Japanese history. His monographs in Japanese include Ronri to rekishi: Higashi ajia bukkyo ronrigaku no keisei to tenkai 論理と歷史: 東アジア佛敉論理學の形成と展開 [Logic and History: Formation and Expansion of Buddhist Logic in East Asia] (Kyoto: Nakanishiya shuppan, 2015) and Daijö-goun-ron wo yomu『大乘五藴論」を讀む [Introduction to Vasubandhu's Pañcaskandhaka] (Tokyo: Shunjūsha, 2015).

E-mail: s-moro@hanazono.ac.jp

International Journal of Buddhist Thought \& Culture Vol. 27. No. 2 (December 2017): 181-204.

(C) 2017 Academy of Buddhist Studies, Dongguk University, Korea

https://doi.org/10.16893/JBTC.2017.12.27.2.181

The day of submission: 2017.10.25.

Completion of review: 2017.11.22.

Final decision for acceptance: 2017.12.3. 


\begin{abstract}
Although the tradition of Buddhist logic in India had been developed through the debates with non-Buddhists, that of pre-modern Japan hardly had such defining experiences. The applications of inmyo were limited to disputes between the Hosso school (the Japanese transmission of the Sinitic Yogäcära school) and another Buddhist schools.

During the rapid modernization and Westernization after the Meiji restoration, however, Buddhist logicians also encountered non-Buddhist cultures, Western-style deductive and inductive logic, Christianity, democracy, and republicanism imported from Western countries. Some of them, such as Kira Köyō, regarded inmyö as useful for democratic discussion, and promoted it among politicians and legal professionals. Their introductory books about inmyo included many sample expressions that criticized the existence of God and the authenticity of republicanism, as well as the unequal treaties forced upon Japan by Europe and America.

In spite of those efforts, inmyo did not become popular in modern Japan. In addition, it also lost scholarly interest in the twentieth century because of the introduction of scriptures associated with Indian logic in Sanskrit and Tibetan. Nevertheless, inmyo studies in the Meiji period should not be ignored because they were regarded as one of the intellectual refutations of the West in East Asia, as well as forgotten previous researches of the Buddhist logic.
\end{abstract}

Key words: Hetuvidyā, Christianity, Republicanism, Kira Kōyō, Modernization in East Asia 


\section{Introduction}

Although the tradition of Buddhist logic in India developed through debate with non-Buddhists, that of pre-modern Japan hardly had such an experience. Japanese Buddhist monks studied Buddhist logic (inmyō) using sample expressions, such as "sound being impermanent," based on Indian philosophical traditions that did not exist in Japan. Their central concern seemed to focus on the sophistication of the interpretation of the scriptures, in particular Ji's (632-682) great commentary of Niyāyapraveśa (Yinming ruzhengli lun shu or Yinming dashu). Applications of inmyō were limited to disputes between the Hossō school (the Japanese transmission of the Sinitic Yogācāra school) and other Buddhist schools, e.g., the debate regarding emptiness and existence, the proof of consciousness-only, and the proof of the distinction in the five natures. ${ }^{1}$

During the rapid modernization and Westernization that followed the Meiji restoration, however, Buddhist logicians also encountered non-Buddhist cultures, including the deductive and inductive logic, Christianity, democracy, and republicanism imported from Western countries. They reconsidered the logical system and merit of inmyō, compared with Western logic, and discussed its reformation. ${ }^{2}$

Some Buddhist logicians regarded inmyō as useful for democratic discussion. Kira Kōyō (1881b), in a traditional commentary on the Yinming dashu, asserts:

To begin with, inmyō is an Indian logic, in which the proponent and opponent debate each other. When one's theory is claimed, [his speech] will stop if it is not logical. If it is logical, [his] speech will be honest and [his] sense of justice will be brave wherever he is, such as in the crowds of the government, the parliament, or the court, or in the presence of sages. And with fearless mind, undaunted tongue, and no waste of words, [he will make his opponent] understand [his opinion] by a simple expression, and he will carry his opinion by concise words. [Inmyō is] a marvelous technique for winning arguments and an essential golden rule in both ultimate reality and mundane truth, in both Buddhist and nonBuddhist [topics], especially in the world of discussion, like today's [society] (emphasis added). ${ }^{3}$

It is reasonable to suppose that Kira used the words "the government, the 
parliament, or the court" and "the world of discussion" in the above statement to echo the social atmosphere at that time: The imperial edict to establish the Imperial Diet was issued in 1881, when Buddhist logicians actively began to publish inmyō works (See Appendix). In addition, according to Asō (2008), the Western logicians in Meiji Japan had also a pragmatic tendency that attempted to solve current topics or real problems using syllogisms. For example, Nishi Amane (1829-1897) claimed that logic was classified into (1) academic studies or logic of kanmon 觀門 (observing approach) and (2) applied research or logic of gyōmon 行門 (practical approach), and it should be studied abstractly as well as utilized in court trials or public speaking (Nishi 1884).

In their publications, the Buddhist logicians introduced the concept of inmyō as well as expressing their personal opinions through sample expressions of inmyo. They not only used traditional articulations, such as "sound being impermanent," but also created new sample expressions concerning modern social issues, such as Christianity, democracy, and so forth, based on their policies. In this paper, I provide a rough overview of the sample expressions regarding Christianity and political issues created by Buddhist logicians in the Meiji period and consider their efforts to expand the applicable ranges of inmyō in modern society.

\section{Criticisms of Christianity using Inmyō}

\section{Anti-Christian Movements in the Meiji period ${ }^{4}$}

When the national isolation policy during the Edo period ended in 1854, and modernization based on Western culture commenced in the Meiji period, the anti-Christian policy of the Edo government was sustained by the Meiji government. In 1873, the Meiji government removed the bulletin board banning Christianity, but did not set forth an administrative policy on Christianity. While Christian missionary work had been active since the 1880s, the anti-Christian movements of Buddhists, Shintoists and politicians had also spread (Sakaguchi 1989a).

Although anti-Christian works published at the end of the Edo period were written based on those of the Ming and Qing dynasties, those published after the Meiji restoration criticized the Bible directly and did not depend on 
Chinese criticisms (Sakaguchi 1989b). Criticizing the problems of Christianity (the dissident character of Christians, missionary activities leading to later colonization, etc.), many of their arguments aimed to proclaim their ideologies, the correctness of the traditional Japanese view of the world, or the sense of ethics, from the standpoint of Buddhism, whether Confucian or Shinto, in Japan.

\section{Kira Kōyō}

Kira Kōyō 雲英晃耀 (1831-1910), called himself Inmyōin 因明院 ([Man from the] Cloister of Logic), was a scholar priest of the Jodo Shin Otani sect from the end of the Edo period to the Meiji period. According to Funayama (1998), Kira Kōyō played a prominent role as an inmyō scholar in the Meiji era along with Ōnishi Hajime 大西祝 (1864-1900) and Murakami Senshō 村上專精 (18511929). ${ }^{5}$

He is known as the author of Gohō sōron 護法總論 (General theory of protecting the Dharma), which, having been published in 1869, is one of the works of Buddhist criticism of Christianity in the Meiji era. In this book, he regarded the Creator of Christianity as a variation of Maheśvara, ${ }^{6}$ and criticized it using inmyō inferences based on Ji's commentary of Chengrweishi lun:

As I discussed above, since the origin of Christianity was one of the 95 nonBuddhist sects serving the gods such as Maheśvara, God's creation of all things corresponds to Maheśvara's ability to create all dharmas. The God without beginning or end is equivalent to the permanence of Maheśvara, and the ubiquitous omniscient God matches the omnipresence of Maheśvara. Therefore, I would like to give the finishing blow to the false doctrine using the seven inferences based on Vasubandhu's Chengrweishi lun that criticized the Maheśvara sect.

The first inference: Your God is definitely not one without beginning or end, because he is a creator, like carpenters and craftsmen. ${ }^{7}[\ldots]$

The second inference: Your God is definitely not ubiquitous, because he is not one without beginning or end, like a bottle. ${ }^{8}[\ldots]$

The third inference: Your God is definitely not omniscient, because he is not ubiquitous, like a bowl. ${ }^{9}$

The fourth inference: Your God could produce instantaneously all things 
everywhere, [if he were ubiquitous,] like a place where a thing is produced. [...] The fifth inference: Your God could produce instantaneously all things anytime, because you stated that the nature [of the God] is omniscient, like a time when a thing is produced. ${ }^{10}[\ldots]$

Given that the heretic claims that all things are not produced everywhere and anytime since [they are produced] after the desires [of the sentient beings] and conditions, while the God is ubiquitous and without beginning or end, this might be in conflict with the proposition that all things are produced by only one cause, namely the Creator. [...]

The sixth inference: The desires [of sentient beings] and conditions can occur even when you claim that the desires and conditions do not occur, because you state that the nature of the God is without beginning and end, like the time when other things occur. [...]

The seventh inference: The desires [of the sentient beings] and conditions can occur even in the place where you claim that the desires and conditions do not occur, because you state that the nature of the God is ubiquitous, like the place where other things occur. ${ }^{11}$

As has been noted, when criticizing based on the way of inmyō, [opponents] might stop their tongue even if [they are] one hundred Christians. ${ }^{12}$

It is reasonable to think that Kira's view of the relationship between the Creator and Maheśvara was influenced by Higuchi Ryūon 樋口龍温 (18001885), ${ }^{13}$ a master of Kira who led the anti-Christian and goho the Buddhist dharma) movements in the Jodo Shin Otani sect. However, he did not use inmyo formulas to prove the problem of the Creator.

Although these inferences are not Kira's originals but are mere rewritings of Ji's criticism of the Maheśvara sect, it is reasonable to think that Kira believed in the effectiveness of inmyō for criticizing Christianity. He published many inmyo books beginning from 1881, when the imperial edict to establish the Imperial Diet was issued, and created new sample expressions on political subjects, as we shall see in the next chapter. Although the Buddhist antiChristian movement became active in the 1880s, there were no sample expressions on Christianity in his books. His critical attitude in this period seemed to have changed from that of an exponent of traditional authorities to of a social activist. 


\section{Murakami Senshō}

Murakami Senshō is known as a pioneer of the academic discipline of Buddhist history in Japan (Klautau 2012), as well as for his argument in the Bukkyo toitsu ron 佛敉統一論 (On the Unification of Buddhism) (from 1901 to 1905) that the Mahāyāna teachings do not stem from the historical Buddha (Mohr 2005; Ward 2005; Shields 2005). His inmyō works, such as Katsuyō köjutsu inmyōgaku zensho 活用講述因明學全書 (Murakami 1891), Bukkyō ronrigaku inmyō ron 佛教論理學因明論 (1898), and so on, however, are little known.

He began to study inmyō under Kira Kōyō from approximately 1877. According to Murakami (1914), Kira invited Murakami to study inmyō and introduce it to the world of genro dōkai 言路洞開 (opening up of voicing one's opinion): ${ }^{14}$

At that time, Master Kira Kōyō said to me: [...] In the civilized world today, namely the world of genro dökai, it is a great pity that inmyo has fallen into disuse. Inmyō is a science of speech. Although it is similar to Western logic, it is different from Western logic in that it organizes and defines the rules of the debate. Since it is to be regretted that little is known about Inmyō today, I would like to investigate Inmyō very hard and introduce it to the world. Why not agree with this? ${ }^{\text {? }}$

Murakami claimed that inmyō should be learned as a common science (futsügaku 普通學), and criticized the traditional description in inmyō works:

Because I did not use traditional sample expressions but systematized new expressions concerning the present issues to describe the logical method of inmyō, this small book is much simpler than conventional well-known inmyō works. [...] Although this book is small, I believe that it will give a glimpse into inmyō studies to those who aim to learn common sciences. [...] Inmyō books of all times were founded on extraordinary sentences, uncommon naming, and syllogisms unconnected with today. Therefore, although they are large in number, they are practically dead. [...] For this reason, I strove to make sentences and naming [in this book] common, and prepare syllogisms concerning modern issues. This is the reason why I used the four characters of katsuyō kōjutsu 活用講述 (utilization lecture) for the title of this book. ${ }^{16}$ 
It is reasonable to suppose that Murakami's practical attitude to inmyō was influenced by Kira. ${ }^{17}$ In contrast to Kira's works, however, Murakami created new sample expressions on Christianity. For example, Murakami (1891) explains the three kinds of inference using sample expressions of God and Jesus. For the explanation of ji biryō 自比量 (the inference for oneself, or the inference using what the proponent only accepts), he created the sample inference quoted below:

Thesis: My God should be revered.

Reason: Because [I] accept that [the God] said that he had deep envy.

Example: Like a devil that $[\mathrm{I}]$ accept. $^{18}$

For ta hiryō 他比量 (the inference for others, or the inference using what the opponent only accepts):

Thesis: Your God is our enemy.

Reason: [You] accept that the charge against the ancestors of humans blamed [by God] has affected us.

Example: Like a devil that [you] accept. ${ }^{19}$

For g $\bar{u}$ biryo 共比量 (the inference for both, or the inference using what both the proponent and opponent accept):

Thesis: Jesus is a general human.

Reason: Because [his body] is not different from general people's bodies.

Example: Like us. ${ }^{20}$

Although the sample expression of $j i$ hiryō is affirmative to Christianity, those of ta biryō and gü biryō are negative and/or hostile. Murakami states that $j i$ biryo is far short of ta biryō and gü hiryō, since it is used only in unavoidable self-defense circumstances. ${ }^{21}$ It is likely that he tried to prove euphemistically that Christianity could not hold true.

\section{Gonda Raifu}

Gonda Raifu 權田雷斧 (1846-1934) was a Buddhist scholar monk of the Buzan sect of Shingon Buddhism (a Japanese esoteric school). He wrote a small piece of inmyō introduction (Gonda 1893) that exhibited a sample inference on Christianity. 
Now, I give a poor example of inference to demonstrate the manner [of inmyō].

A Buddhist states his proposition to a Christian:

Jesus Christ is not the Savior (thesis).

Because [he was] nailed on the cross and killed (reason).

Anyone who is nailed on the cross and killed, such as a criminal, should not be regarded as the Savior (homologous example).

All saviors should be regarded as those who are not nailed on the cross and killed. There are no actual examples to demonstrate. (heterologous example) ${ }^{22}$

Since Gonda regarded this sample inference as a logically valid one, the thesis ("Jesus Christ is not the Savior") is logically true from his point of view. It seems appropriate to suppose that this inference is also a representation of his standpoint towards Christianity.

\section{Inferences on Political Issues}

\section{Kira Kōyō}

As I mentioned above, Kira began to publish inmyō works aggressively from 1881, when the imperial edict to establish the Imperial Diet was issued. According to Kira et al. (1890), on December 14, 1882, he gave an inmyō lecture at the request of Matsuoka Yasukowa 松岡康毅 (1846-1923), who was the president of the appellate court of Hiroshima, and began actively lecturing on inmyō to politicians and lawyers throughout Japan. After 1890, the year of the first general election of the members of the House of Representatives, his writing activity to promote inmyō seemed to end.

For those lectures, Kira used his introductory books such as Inmyō shoho 因明初歩 (1881) and Inmyō taii i 因明大意 (1881). In those works, he repeatedly claimed that inmyo should be used for discussion in the government, the parliament, or the court, and gave many sample expressions based on the political issues at that time, except for Christianity.

For instance, Kira used an example of a three-part formula to criticize unequal treaties between Japan and Europe:

Thesis: Japan and so forth can punish a person who has broken the law, based 
on their own laws.

Reason: Because they are independent empires.

Homologous example: Like the Russian Empire.

Heterologous example: Like the British India. ${ }^{23}$

Another example from Inmyō katsugen (Kira 1884) expressed opposition to the introduction of republicanism in terms of son'no o 尊王 thought (a view that advocates reverence for the Emperor of Japan):

Recently in our country, however, there are some people who like to discuss politics and laws following the moment of genro dökai. In addition, although born in the Empire [Japan], there are a few people who forget the nationality that has no equal in the world and flatter the republicanism of the States. [...] Although the inference stated below is not faultless and complete in the manner of the three-part formula, [...], I would like to create the new inference to demonstrate a part of utility of inmyo for advocates in the world and to demolish the shameless fallacy [of republicanists]. [...] Now, the ideologue of son'nō thought makes an inference against the republicanist and argues:

Thesis: The principle of our country that the imperial lineage should determine the ruler [of Japan] should not ever be changed.

Reason: Because it is an imperial order of an ancestor of the Emperor.

Homologous example: Like heaven and earth [which were apprehended as the eternal by the ancestor].

Heterologous example: Like the game of go 碁. ${ }^{24}$

He also explained jāt $i$ 過類 regarding a republicanist as the opponent. It is clear that he was critical of republicanism.

Kira suggested restructuring inmyō in the style of an Aristotelian syllogism and called it shin-shin inmyō 新々因明 (new-new inmyō), compared with Dignāgean logic, which was sometimes called shin inmyō 新因明 (new inmyō). It consists of two groups of syllogism: hyöken shiki 表顯式 (positive syllogism) and hanken shiki 反顯式 (contradictory syllogism). For demonstration, he used the following example dealing with the Freedom and People's Rights Movement (Jiyü minken undō 自由民權運動) in the 1880s:

A police officer, confronting a public speaker, argues: 


\section{- Hyōken shiki}

First step: Like a certain public speech by Kō 甲 (homologous example), all public speeches recognized as sedition (reason) should be suppressed and dispersed (thesis).

Second step: Your public speech (thesis) is recognized as sedition (reason).

Third step: Therefore, your public speech should be suppressed and dispersed (whole thesis).

\section{- Hanken shiki}

First step: Like a certain public speech by Otsu 乙 (heterologous example), all speeches that should not be suppressed and dispersed (thesis) are not public speeches recognized as sedition (reason).

Second step: Your public speech (thesis) is recognized as sedition (reason).

Third step: Therefore, your public speech should be suppressed and dispersed (whole thesis). ${ }^{25}$

This sample expression shows Kira's opposing position to free speech. I would like to focus attention on Kira's attitude to free speech, since, needless to say, free speech is one of the fundamental elements of democracy and Kira emphasized the importance of inmyo at a public discussion as we have seen before.

\section{Takashi Dairyō and Nanjō Bun'yū}

Inmyō taìi (1887) was an informative guide of inmyō written by Takashi Dairyō 高志大了 (1834-1898), a scholar monk of the Shingon sect, and Nanjō Bun'yū 南條文雄 (1849-1927), who is well known for his introduction of European Buddhist studies to Japan and his studies of Sanskrit Buddhist texts. They showed a sample example on a social problem for beginners:

The first issue of Toron hikki 討論筆記 [Reports of Debates] edited by Maruyama Namasa 丸山名政 reported a discussion as to whether or not the government should shoulder the relief of the poor. ${ }^{26}$ In this case, the proponent could make inference for both [the proponent and opponent] against the opponent [like this]:

Thesis: The government (dharmin) has the duty to shoulder the law of the relief 
of the poor.

Reason: Because it takes pleasure in equalizing our society's happiness.

Homologous example: Like a benevolent person.

Heterologous example: Like a sly person. ${ }^{27}$

The sample inference is a rewrite of a part of the actual discussion reported in Tóron bikki. It is difficult to judge from this short example whether or not the inference expresses their policies.

\section{Conclusion}

As introduced above, some Buddhist logicians tried to apply inmyō to actual problems, particularly those caused by modernization and Westernization after the Meiji restoration. They seemed to believe in the effectiveness of inmyo as being equivalent to or better than Western logic. In particular, the promotional activities of Kira Kōyō are noteworthy. He attempted to reform the syllogism of inmyo to enhance the performance of inmyō. Since the tendency of the Japanese inmyō scholarship had been exegetical and commentarial, Kira's proposal of "new-new inmyo" was a very exceptional case, even though inmyō was merely an instrument for self-expression for many Buddhist logicians in Meiji Japan.

In spite of their efforts, inmyō did not become popular in modern Japan. In addition, scholars were disinterested in this kind of logic in the twentieth century, due to the introduction of the scriptures of Indian logic in Sanskrit and Tibetan. ${ }^{28}$ However, inmyō studies in the Meiji period should not be ignored, since it can be regarded as one of the intellectual refutations to the West in modernizing East Asia. John Jorgensen (2014) discusses the international network between Japanese Buddhist logicians in the Meiji period and Chinese scholars of Buddhism, such as Song Shu 宋恕 (1862-1910) and his friend Zhang Taiyan 章太炎 (1869-1963), who is also well-known as an important revolutionary in modern China. In early modern East Asia, inmyō or yinming might be one of the reliable traditions for intellectuals to confront the issues raised by the rapid modernization or Westernization, regardless of their positions or purposes. 


\section{Appendix: Inmyō Works in the Meiji Era}

\begin{tabular}{|c|c|c|}
\hline Date & Title & Author, Editor \\
\hline Oct., 1877 (Meiji 10) & $\begin{array}{l}\text { Inmyō nissōri ron chüsho kazu } \\
\text { 因明入正理論註疏科圖 }\end{array}$ & $\begin{array}{l}\text { Kishigami Kairei 岸上恢嶺 } \\
(1839-1885)\end{array}$ \\
\hline Nov., 1879 (Meiji 12) & $\begin{array}{l}\text { Inmyō shöri mon ron kazu } \\
\text { 因明正理門論科圖 }\end{array}$ & $\begin{array}{l}\text { Kira Kōyō (1831-1910) and } \\
\text { Nagai Shōdō 永井昇道 (date } \\
\text { of birth and death unknown) }\end{array}$ \\
\hline Dec., 1881 (Meiji 14) & $\begin{array}{l}\text { Inmyō nissöri ron hōgüroku } \\
\text { 因明入正理論疏方隅錄 }\end{array}$ & Kira Kōyō \\
\hline Apr., 1881 (Meiji 14) & $\begin{array}{l}\text { Inmyō sanjüsan ka högüroku } \\
\text { 因明三十三過方隅錄 }\end{array}$ & Kira Kōyō \\
\hline Oct., 1881 (Meiji 14) & Inmyō shoho 因明初歩 & Kira Kōyō \\
\hline Oct., 1881 (Meiji 14) & Inmyōtaīi 因明大意 & Kira Kōyō \\
\hline Oct., 1881 (Meiji 14) & $\begin{array}{l}\text { Inmyō nissōri ron kachū } \\
\text { 因明入正理論科註 (Reprint) }\end{array}$ & Musō 無相 (1757-1825) \\
\hline Nov., 1881 (Meiji 14) & Inmyō nissōri ron sho 因明入正理論疏 & Kira Kōyō \\
\hline Apr., 1884 (Meiji 17) & $\begin{array}{l}\text { Inmyō sanjūsan ka honsahō kahon } \\
\text { 因明三十三過本作法科本 }\end{array}$ & Kira Kōyō \\
\hline May, 1884 (Meiji 17) & Inmyō shoho, 2nd eds. & Kira Kōyō \\
\hline May, 1884 (Meiji 17) & Inmyō taiłi, 2nd eds. & Kira Kōyō \\
\hline May, 1884 (Meiji 17) & Inmyō katsugen 因明活眼 & Kira Kōyō \\
\hline Nov., 1884 (Meiji 17) & $\begin{array}{l}\text { Inmyō nissōri ron kahon } \\
\text { 因明入正理論科本 }\end{array}$ & Kira Kōyō \\
\hline Jul., 1885 (Meiji 18) & $\begin{array}{l}\text { Inmyō nissōri ron kahon } \\
\text { 因明正理門論科本 }\end{array}$ & Kira Kōyō \\
\hline Aug., 1885 (Meiji 18) & $\begin{array}{l}\text { Inmyō nissōri ron yoben } \\
\text { 因明入正理論與便 }\end{array}$ & $\begin{array}{l}\text { Kitabatake Dōryū 北香道龍 } \\
(1820-1907)\end{array}$ \\
\hline Aug., 1885 (Meiji 18) & $\begin{array}{l}\text { Inmyō sanjūsan ka kōgi } \\
\text { 因明三十三過本作法講義 }\end{array}$ & Kira Kōyō \\
\hline
\end{tabular}




\begin{tabular}{|c|c|c|}
\hline Date & Title & Author, Editor \\
\hline May, 1886 (Meiji 19) & $\begin{array}{l}\text { Inmyō nissōri ron kachū kōhon } \\
\text { 因明入正理論科註校本 }\end{array}$ & $\begin{array}{l}\text { Ōuchi Seiran 大内青巒 } \\
\text { (1845-1918) }\end{array}$ \\
\hline Nov., 1887 (Meiji 20) & Inmyō tai’i 因明大意 & $\begin{array}{l}\text { Takashi Dairyō 高志大了 } \\
\text { (1834-1898) and Nanjō } \\
\text { Bun'yū 南條文雄 (1849-1927) }\end{array}$ \\
\hline Feb., 1888 (Meiji 21) & $\begin{array}{l}\text { Inmyō sanjūsan ka honsahō sange } \\
\text { 因明三十三過本作法纂解 }\end{array}$ & $\begin{array}{l}\text { Sugihara, Shundō 杉原春洞 } \\
\text { and Sebe, Etō 瀬邊惠燈 (d.u.) }\end{array}$ \\
\hline Mar., 1888 (Meiji 21) & $\begin{array}{l}\text { Bukkyō enzetsu tatsuben no jutsu } \\
\text { 佛敎演說達弁之術 }\end{array}$ & $\begin{array}{l}\text { Itō Yōjirō 伊東洋二郎 and } \\
\text { Sakaguchi Magane 阪口鐵 } \\
\text { (d.u.) }\end{array}$ \\
\hline Apr., 1888 (Meiji 21) & $\begin{array}{l}\text { Inmyō nissōri ron kōsan } \\
\text { 因明入正理論講讃 }\end{array}$ & Zōun 雜雲 (1824-1884) \\
\hline Apr., 1888 (Meiji 21) & $\begin{array}{l}\text { Inmyō nissōri ron yōroku } \\
\text { 因明入正理論要錄 }\end{array}$ & $\begin{array}{l}\text { Hōun 寶雲 (1791-1847) and } \\
\text { Sanada Jitsujō 眞田實淨 (d.u.) }\end{array}$ \\
\hline Nov., 1888 (Meiji 21) & $\begin{array}{l}\text { Inmyō nissōri ron kachū } \\
\text { 因明入正理論科註 }\end{array}$ & $\begin{array}{l}\text { Kishigami Kairei and } \\
\text { Yanagisawa Kōson 柳澤迎存 } \\
\text { (d.u.) }\end{array}$ \\
\hline Jan., 1889 (Meiji 22) & $\begin{array}{l}\text { Kairyō shinsen sekkyō gaku } \\
\text { 改良新撰說呚學 }\end{array}$ & $\begin{array}{l}\text { Ozawa Yoshiyuki 小澤吉行 } \\
\text { (d.u.) }\end{array}$ \\
\hline Mar., 1889 (Meiji 22) & $\begin{array}{l}\text { Töyō shinshin inmyō hakki: ichimei } \\
\text { nihon katsu ronri 東洋新々因明發揮: } \\
\text { 一名日本活論理 }\end{array}$ & Kira Kōyō \\
\hline $\begin{array}{l}\text { Jul., Sep., and Oct., } \\
1889 \text { (Meiji 22) }\end{array}$ & $\begin{array}{l}\text { “Inmyō ni tsukite 因明につきて,”1-3. } \\
\text { Tetsugaku kai zasshi 哲學会雑誌, 3(29, } \\
\text { 31,32). }\end{array}$ & Ōnishi Hajime (1864-1899) \\
\hline Aug., 1889 (Meiji 22) & $\begin{array}{l}\text { Inmyō nissōri ron kōgi } \\
\text { 因明入正理論講義 }\end{array}$ & $\begin{array}{l}\text { Yoshida Shōon 吉田清音 } \\
\text { (d.u.) and Terao Kakuen } \\
\text { 寺尾覺演 (d.u.) }\end{array}$ \\
\hline Oct., 1889 (Meiji 22) & $\begin{array}{l}\text { Shügaku senmon kō shaken hikkiroku } \\
\text { 宗學專門校試験筆記録 }\end{array}$ & $\begin{array}{l}\text { Takashima Takashi 高島隆 } \\
\text { (d.u.) }\end{array}$ \\
\hline Jan., 1890 (Meiji 23) & $\begin{array}{l}\text { Tōyō ronri ippan: ichimei inmyō gaku } \\
\text { 東洋論理一斑: 一名因明學 }\end{array}$ & Wada Daien 和田大圓 (d.u.) \\
\hline Mar., 1890 (Meiji 23) & Tsūzoku inmyō gaku 通俗因明學 & Itō Yōjirōō \\
\hline
\end{tabular}




\begin{tabular}{|c|c|c|}
\hline Date & Title & Author, Editor \\
\hline Jun., 1890 (Meiji 23) & $\begin{array}{l}\text { Töyō shinshin inmyō ippan } \\
\text { 東洋新々因明一玟 }\end{array}$ & Kira Kōyō \\
\hline $\begin{array}{l}\text { Aug. and Oct., } 1890 \\
\text { (Meiji 23) }\end{array}$ & $\begin{array}{l}\text { “Kira Kōyō shi no doku } \\
\text { tetsugaku kai zasshi inmyō ron } \\
\text { 雲英晃耀氏の読哲學会雑誌因明論," } \\
\text { 1-2. Tetsugaku kai zasshi 4(42,44). }\end{array}$ & Ōnishi Hajime \\
\hline Dec., 1890 (Meiji 23) & $\begin{array}{l}\text { Inmyō gaku kyōkai houkoku } \\
\text { 因明學協会報告 }\end{array}$ & $\begin{array}{l}\text { Kira Kōyō and Kira Ryūgo } \\
\text { 雲英竜護 (d.u.) }\end{array}$ \\
\hline Sep., 1891 (Meiji 24) & $\begin{array}{l}\text { Hyōdō inmyō nissōri ron kachū } \\
\text { 評導因明入正理論科註 }\end{array}$ & $\begin{array}{l}\text { Hiro’oka Ryōei 廣陵了栄 } \\
\text { (d.u.) }\end{array}$ \\
\hline Nov., 1891 (Meiji 24) & $\begin{array}{l}\text { Katsuyō kōjutsu inmyō gaku zensho } \\
\text { 活用講述因明學全書 }\end{array}$ & $\begin{array}{l}\text { Murakami Senshō (1851- } \\
\text { 1929) }\end{array}$ \\
\hline 1891 (Meiji 24) (?) & $\begin{array}{l}\text { Ronri gaku 論理學 (a lecture record } \\
\text { of Tokyō senmon gakkō) }\end{array}$ & Ōnishi Hajime \\
\hline Feb., 1892 (Meiji 25) & $\begin{array}{l}\text { Kötei inmyō nissöri ron zokusen } \\
\text { 校訂因明入正理論俗詮 }\end{array}$ & $\begin{array}{l}\text { Gihan 義範 (1023-1088) and } \\
\text { Chikuwan 竹灣 (d.u.) }\end{array}$ \\
\hline $\begin{array}{l}\text { Jun., and Oct., } 1892 \\
\text { (Meiji 25), Jan., Apr., } \\
\text { Jul., and Sep., } 1893 \\
\text { (Meiji 26) }\end{array}$ & $\begin{array}{l}\text { “Keishiki teki ronri gaku no sandan } \\
\text { ronpō, inmyō no sanshi sahō } \\
\text { narabini Miru no kinōsoku wo } \\
\text { ronzu 形式的論理學の三段論法、因明の } \\
\text { 三支作法并びにミルの歸納則を論ず.” } \\
\text { Tetsugaku zasshi, } 7(64,68,71), 8(74 \text {, } \\
77,79) .\end{array}$ & Ōnishi Hajime \\
\hline Feb., 1893 (Meiji 26) & $\begin{array}{l}\text { Inmyō nissōri ron kōgi } \\
\text { 因明入正理論講義 }\end{array}$ & Kira Kōyō \\
\hline Jul., 1893 (Meiji 26) & $\begin{array}{l}\text { Tōyō ronri hō inmyō rakusōo } \\
\text { 東洋論理法因明落草 }\end{array}$ & Gonda Raifu (1846-1934) \\
\hline Aug., 1893 (Meiji 26) & Kira Kōyō shi kōwa 雲英晃耀師講話 & Kira Kōyō \\
\hline Dec., 1893 (Meiji 26) & $\begin{array}{l}\text { Inmyō ron sho keimon shohen } \\
\text { 因明論疏啓門 初編 }\end{array}$ & $\begin{array}{l}\text { Terajima Ichibun 寺島一文 } \\
\text { (d.u.) }\end{array}$ \\
\hline Jan., 1894 (Meiji 27) & $\begin{array}{l}\text { Enzetsu tatsuben hō: Seiji gakujutsu } \\
\text { 演說達弁法: 政治學術 }\end{array}$ & Tankai Sanshi 淡海散士 (d.u.) \\
\hline
\end{tabular}




\begin{tabular}{|c|c|c|}
\hline Date & Title & Author, Editor \\
\hline Aug., 1894 (Meiji 27) & $\begin{array}{l}\text { Ehon saiji inmyō nissōri ron hōgū } \\
\text { roku 會本再治 因明入正理論疏方隅錄 }\end{array}$ & Kira Kōyō \\
\hline Sep., 1894 (Meiji 27) & Inmyō wakumon 因明或問 & $\begin{array}{l}\text { Matsu'ura Shūdō 松浦周道 } \\
\text { (d.u.) }\end{array}$ \\
\hline 1895 (Meiji 28) & $\begin{array}{l}\text { Ronrigaku 論理學 (a lecture record } \\
\text { of Tokyō senmon gakkō) }\end{array}$ & Ōnishi Hajime \\
\hline Feb., 1897 (Meiji 30) & Gedō tetsugaku 外道哲學 & Inoue Enryō (1858-1919) \\
\hline Mar., 1897 (Meiji 30) & Inmyō gaku no gairyaku 因明學之概略 & $\begin{array}{l}\text { Hatakeyama Shōzō 畠山省三 } \\
\text { (d.u.) }\end{array}$ \\
\hline Sep., 1897 (Meiji 30) & $\begin{array}{l}\text { Bukkyō tsūzoku kōgi: Inmyō } \\
\text { gaku tai’i, Sanjūsan ka } \\
\text { honsahō kōgi 佛教通俗講義: } \\
\text { 因明學大意·三十三過本作法講義 }\end{array}$ & $\begin{array}{l}\text { Murakami Senshō and } \\
\text { Ikehara Gaju (1850-1924) }\end{array}$ \\
\hline Nov., 1897 (Meiji 30) & $\begin{array}{l}\text { Ikyō taiwa: ichimei inmyō jutsu } \\
\text { 異敎對話: 一名因明術 }\end{array}$ & $\begin{array}{l}\text { Ama Tokumon 阿滿得聞 } \\
\text { (1826-1906) }\end{array}$ \\
\hline 1897 (Meiji 30) & $\begin{array}{l}\text { 論理學 (a lecture record of Tokyō } \\
\text { rigakusenmon gakkō) }\end{array}$ & Ōnishi Hajime \\
\hline 1898 (Meiji 31) & Bukkyō rika kōgi 佛教理科講義 & Inoue Enryō \\
\hline 1898 (Meiji 31) & $\begin{array}{l}\text { Bukkyō ronri gaku inmyō ron } \\
\text { 佛㸚論理學因明論 }\end{array}$ & Murakami Senshō \\
\hline Jul., 1898 (Meiji 31) & Indo tetsugaku kōyō 印度哲學綱要 & Inoue Enryō \\
\hline Sep., 1899 (Meiji 32) & $\begin{array}{l}\text { Yūben biji hō: Enzetsu tōron } \\
\text { 雄弁美辞法: 演說討論 }\end{array}$ & $\begin{array}{l}\text { Tōyama Keifuku 遠山景福 } \\
\text { (d.u.) }\end{array}$ \\
\hline May, 1903 (Meiji 36) & Inmyō gaku kōyō 因明學綱要 & Imai Seikichi 今井清吉 (d.u.) \\
\hline Feb., 1904 (Meiji 35) & $\begin{array}{l}\text { Ronrigaku 論理學 (Collected works } \\
\text { of Dr. Ōnishi Hajime, Vol. 1) }\end{array}$ & Ōnishi Hajime \\
\hline Jan., 1908 (Meiji 41) & Ronrigaku kōgi 論理學講義 & $\begin{array}{l}\text { Kitagawa Sadakichi 北澤定吉 } \\
\text { (d.u.) }\end{array}$ \\
\hline Mar., 1908 (Meiji 41) & Yūben hōo 雄弁法 & $\begin{array}{l}\text { Katō Totsudō 加藤咄堂 } \\
(1870-1949)\end{array}$ \\
\hline
\end{tabular}




\begin{tabular}{c|l|l}
\hline Date & \multicolumn{1}{|c|}{ Title } & \multicolumn{1}{|c}{ Author, Editor } \\
\hline May, 1909 (Meiji 42) & Tōō ronri gaku shi 東洋論理學史 & $\begin{array}{l}\text { Kamura Gien 香村宜圓 } \\
(1880-1946)\end{array}$ \\
\hline Sep., 1910 (Meiji 43) & $\begin{array}{l}\text { Zōtei saishin ronri gaku yōgi } \\
\text { 増訂最新論理學要義, } \text { 3 }^{\text {rd }} \text { ed. }\end{array}$ & $\begin{array}{l}\text { Imafuku Shinobu 今福忍 } \\
(1873-1923)\end{array}$ \\
\hline
\end{tabular}




\section{Notes}

1 Moro (2015b) is a comprehensive study on the debates in East Asia, especially focusing on the proof of vijñaptimātratā attributed to Xuanzang.

2 As will be shown later, Kira Kōyō proposed the new-new inmyō 新々因明, a reformation of the three-part formula based on Aristotle's syllogism (Moro 2015a).

3 抑因明八印度ノ論理法ニシテ其法タル立敵對揚シ自己ノ持論ヨ主張スルニ當リ條理ナクンハ 止ン荷モ條理アラ八政府議院裁判所多人衆ノ中或八賢哲者ノ面前等何タル處所二於テモ言論 敦肅義気勇猛ニシテ意二畏レナク言二屈スルナク徒二多言ヨ費サス言簡ニシテ義通シ語少二 シテ旨貫キ勝ヨ論塲二占ムヘキ妙術ニシテ眞二就キ俗二就キ内二就キ外二就キ社会ノ間二一 日モ欠クヘカラサル金科玉條ナリトス殊二方今/如キ議論世界二於テヨヤ (Kira 1881b, 1)

4 See also Thelle (1987).

5 See also Moro (2015a).

6 In his short article "Inga hōni setsu 因果法爾說 (An Explanation of the Law of Cause and Effect)” (1882), Yoshitani Kakuju 吉谷覺壽 (1843-1914) also thought that God was similar to Maheśvara. He was also a scholar priest of the Jodo Shin Otani sect and is known as a teacher of Inoue Enryō 井上圓了 (1858-1919) at the University of Tokyo. See Sato (2015).

7 Cf. 量云、大自在天決定非常。是能生故。如地水等。(Chengrweishi lun shuji, T 43, 262b2-3)

8 Cf. 大自在天決定非遍。以非常故。如瓶等物。(ibid, T 43, 262b7-8) The original “本等者” might be the writing error of “瓶等物.”

9 Cf. 又非眞實。以不遍故。如盆等物。(ibid, T 43, 262b8-9)

10 Cf. 體既遍而且是常、遍故何不於一切處、常故何不於一切時、能生諸法。如彼現生處及時等。 遍故。常故。即二因也。此中二量前三爲五。(ibid, T 43, 262b13-16)

11 Cf. 汝復若謂體雖遍常、以待樂欲并及緣故、諸法不一切處及一切時生者、今汝宗言唯大自在 一法爲因、復言更待諸衆生欲及諸法緣、即多法爲因、豈不便違一因生論。[...] 大自在因一切 時有、以是常故、何不衆生欲及緣一切時頓生。量云、汝言無欲及緣起時欲緣應起。許自在天體 恒有故。如餘起時。此同瑜伽第六七說。不能繁引。(ibid, T 43, 262b18-26)

12 然ル二先二辯ズル如ク、カノヤソノ本家八九十五種ノ外道ノ中デ八、大自在天等ノ事天外道ノ 所立ナルガ故、天主ノ能生一切萬物卜云ウガ自在天ノ能生諸法ニアタリ、天主ノ無始無終卜 云フガ自在天ノ常住ト云フニアタリ、天主ノ無所不在无所不知卜云フガ自在天ノ周遍自在二 アタル。故二世親論主唯識論二大自在天外道习破シ玉フ處ノ能破二順ジテ、七ケノ量ヨ立テ テ彼邪道二止メヨサスベシ。第一二立量シテ云フ。汝ガ天主八決定シテ無始無終ニアラザルベ シ。能造ノモノト云フガ故二、工匠等ノ如シ。 [...] 第二二立量シテ云、汝ガ天主八決定シテ無所 不在二八非ルベシ、無始無終二非ルヨ以テ、平等ノ者ノ如シ。[...] 第三立量シテ云、汝ガ天主八 決定シテ無所不知二八非ルベシ、無所不在ニ非ルガ故二、盆等ノ者ノ如シ。 $[. .$.$] 第四二立量シ$ テ云、汝天主八一切處二オイテ、頓二一切法ヨ生ズベシ、カノ現二生ズル所ノ如シ。[...]第五立 量シテ云ク、汝天主八、一切時ニオイテヨク諸法ヨ生ズベシ。體スデニ無始無終ト云フガユユニ、 カノ現二生ズル時ノ如シ。 $[. .$.$] 此義习第六二立量シテ云、汝欲卜及ビ緣起ルコトナシト云フト$ キモ、欲卜緣トマサニオコルベシ。天主ノ體無始無終トユルスガユュニ、余ノオコルトキノ如シ。 
[...] 又處ᄏ難ズル量ヨ第七二立テ云ク、汝欲ト及ビ緣オコルコトナシト云フ。處二モ、欲卜緣卜 マサニオコルベシ。天主/體無所不在トユルスガユユニ、余ノオコルトコロノ如シ。如此因明論 道ヨ以テ、立量シテ難ゼバ、百ヤソ出ルト云ヘドモ、恐ラク舌ヨ盡シテヤミヌベシ。(Tokushige 1935, 303-304)

13 ...凡 凡今時歐羅巴ノ全洲并ニミリカノ合衆国、弘儿處ノ耶蘇敎、此度關東横濱ノ夷人ミ十是 ヨ宗トスル。此敎海外二盛ント起ルコト實二慨嘆スベシ。其大意八全ク耶蘇卜イヘル者ガ立ル 處ノ教ニシテ、其本八古ク天竺二伝ル事天外道ナルコト必七リ。別シテイヘバ大自在天ノ計ヨ リ出ルト、私二八左様ニスハリテ見ル心也。(Tokushige 1935,146)

14 For details of genro dōkai, see Lai (2013).

15 この時雲英茪耀師が吾輩に対して言へるやう、[… 今日の文明世界、即ちこの言路洞開の世の 中にあつて、この因明学の廃れて居るのは、如何にも残念である。因明は言論の学問である。西

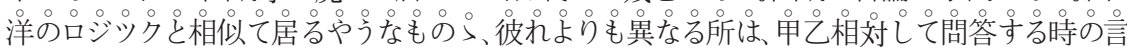

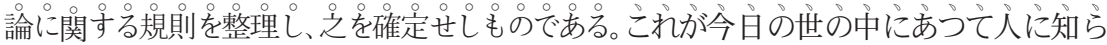
れぬ亡いふこうは誠に惜む゙べき次第である。依て我れ是より此の因明学を大に研究じ世 界に之れを紹介せん亡思、貴公も之に同意しては如何といふ相談であゔた(Murakami 1914, 167-169)

16 余八古来慣用ノ論法习用ヒス、凡テ現今ノ事件二就テ新工夫ノ論法ヨ組織シ、以テ因明ノ論理 法习說明スルカ故二、古来流行, 因明書二比スレ八大二簡略十ル一小册子卜ナレリ。[...]一小册 子ナレトモ、余八此二テ普通学二志ス者ノ因明学一班习知ラントスルニ八事足レリト信スル者ナ リ。[...] 古今因明学ノ書籍八 [...] 其文章ノ通常ナラサルト、其名目ノ普通十ラサルト、其論法 ノ今日二関係ナキ事柄ナルトノ三件二原由スルモノナリ。故二其書多シト雖モ、殆卜死物卜成レ ル状況ナリ。[...]故二余八務メテ文章并二名目 ᄏ普通二シ、且ツ論法八凡テ現今ノ事情二就テ設 ケタリ。是レ本書ノ題上二活用講述ノ四字习冠ラセタル所以ナリ。(Murakami 1891, 3-4).

17 According to Murakami (1914, 269-270), Inoue Enryō’s Bukkyō katsuron joron also had an effect on Murakami's pragmatism.

18 宗我が神は畏敬すへし/因自ら娽妬の心深しと云と許すが故に/喻許す魔鬼の如し

(Murakami 1891, 176).

19 宗汸が神は吾人の怨敵なるべし/因人祖を各むるの餘冤後裔の吾人に及ふと許すが故に／喻 許す魔鬼の如し (Murakami 1891, 178-179).

20 宗 耶蘇は通常一般の人類なるへし/因 普通人種の體軀に異ならざるが故に/喻 吾人の如し (Murakami 1891, 181).

21 凡ソ斯ノ如キ自比量ノ論法八止 7 得サルニ出ルモノナレハ 其共比量他比量二及ハサル 遠シ 只是レ立者自家ノ城廊ヨ漸ク二保チ得ル迄二止リテ 敵者习進撃スル力モナク又敵者习誘フテ 立者ノ主義二同意セシムルフモ能八サル自守的論法ナルモノ也 (Murakami 1891,178).

Murakami's understanding of ji biryō is quite different from the Indian concept of svārtha-anumāna.

22 今且ク愚案ノ一比量 $\ni$ 提出シテ之二就テ作法ヨ示サン謂ク佛敎者力耶蘇敉徒二對シテ立量シ テ云ク

耶蘇基督非救世主(宗)釘十字架死故(因)

諸釷十字架死者見彼皆非救世主唒如餘犯罪人(同喻) 
諸救世主者見彼皆非釘十字架死喻依無法不舉之(異喻)(Gonda 1893, 3-4).

23 日本人民英仏等ノ政府二対シテ立量シテ云ク

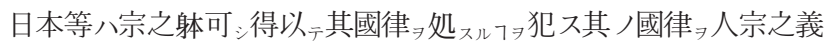

獨立, 帝國十ルカ故二因

唒: 如:魯國, 同喻

唒: 如: 英領印度等, 異喻 (Kira 1881, 6-7).

24 然ル二近頃本邦言路洞開ノ盛時二乘ジ或八好ミテ政习議シ律ヨ論ジ甚キ二至リテハ其ノ身皇 國二生レ乍ラ掛ケ卷モ畏キ万國無比ノ御國体アルヨ忘レ動モスレバ彼ノ合衆國ノ共和ノ政治 ヨ艶稱スルモノ世間未ダ必ズシモ其ノ人ナカラズトス忌ミ憚リナキノ甚キ者卜云フベシ [...] 今マ立スル所ノ本量八三支作法二於テ無過圓滿二八非ザルベケレドモ $[. .$.$] 別二一箇ノ新比量$ ヨ建立シ以テ此, 因明活用ノ一斑 7 世間ノ論士二識知七シメ併七テ彼ノ無忌無憚ノ妄論 7 粉 碎塵散セシメント欲ス [...] サテ尊王論師ガ共和論師二対シテ正二立量シテ云ク

我力國,皇統可王, 有法長二不可，変又能别

天祖, 遺敕十ルカ故二因

唒: 如: 天壤, 同喻

唒:如: 奕碁等, 異喻 (Kira 1884, 22-24).

25

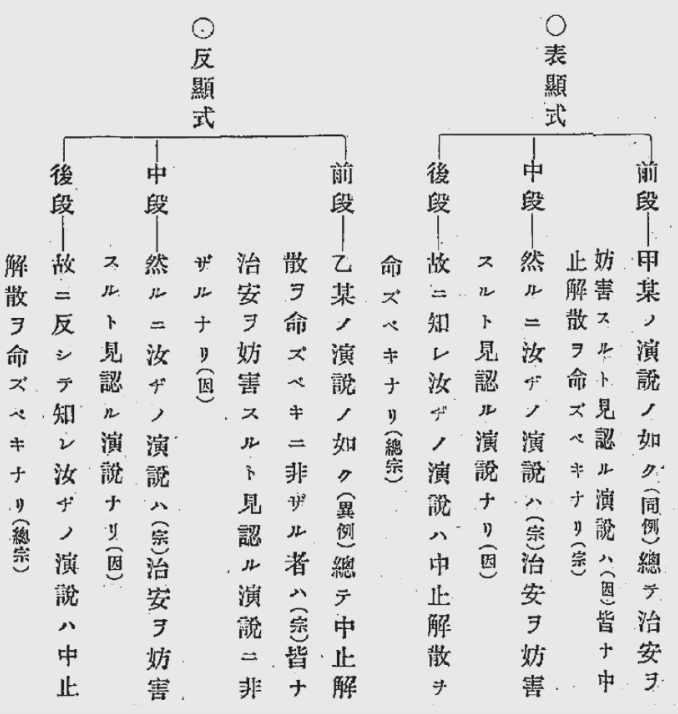

(Kira 1889, 90-92).

26 Maruyama (1881, 12-26). This discussion was held at Kokuyūkai 國友会, a political enlightenment group established in 1880. Maruyama (1881) also includes other discussions regarding the legislative power of judges, the public election of judges, and women's suffrage.

27 丸山名政氏 $\exists$ 編輯セル討論筆記第一號ノ中二 貧民救助 7 政府二負担スル義務アリヤ否ヤト 論アリ今発論者ヨ以テ立者卜シ反対論者 ヨ以テ敵者卜シ共比量 7 成七バ 政府 <有法>八 
極貧民救助法ヨ負擔スル義務アルベシ(宗)吾人社会ノ幸福ヨ均フスルヨ愉快トスルガ故二(因) 慈仁者ノ如シ(同喻)悪奸者ノ如シ(異喻) (Takashi and Nanjō 1887,6).

$28 \mathrm{My}$ paper on the inmyō studies in Meiji Japan will be published in Chinese, titled “Míngzhì shíqī de yīnmíng yánjiū” 明治时期的因明研究. It will summarize the trend of research of Indian logic in the early twentieth century in Japan. 


\section{References}

\section{Primary Sources}

Gonda, Raifu Töyō ronri inmyō rakusō [A Note on the Method of Eastern Logic, 1893 Inmyō]. Niigata: Honma Ichisaku.

Higuchi, Ryūon Hekija gohō saku [Plan to Attack the Heterodox and Defend the 1863 Faith]. In Meiji Bukkyō zenshü [Collection of Buddhist Books in the Meiji Era], 8. Ed. Tokushige Asakichi. Tokyō: Shun'yōdō, 1935.

Kira, Kōyō Inmyō taìi [Summary of Inmyō]. Kyoto: Kira Kōyō.

$1881 \mathrm{a}$

1881b Inmyō nisshōriron sho hōgüroku [Introductory Commentary of Yinming-ruzhengli-lun-shu]. Kyoto: Kira Kōyō.

1884 Inmyō katsugen [Piercing eyes of Inmyō]. Kyoto: Kira Kōyō.

1889 Tōyō shinshin immyō hakki: Ichimei nihon katsu-ronri [Demonstration of Eastern New-new Inmyō, a.k.a. Japanese Practical Logic]. Aichi: Kira Kōyō.

Kira Kōyō, Inmyōgaku kyōkai houkoku [Report on the Association for Inmyō et al. Studies]. Aichi: Inmyōgaku kyōkai.

1890

Maruyama, Namasa Tōkyō kakusha tōron hikki [Reports of Debates], 1. Tokyo: 1881 Chitsuzandō.

Murakami, Senshō Katsuyō köjutsu inmyōgaku zensho [Utilization Lecture of Inmyō]. 1891 Tokyo: Testugaku shoin.

1914 Rokujüichi nen [61 Years]. Tokyo: Heigo shuppansha

Nishi, Amane Ronri shinsetsu [New theory of logic]. 1884

Takashi, Dairyō and Inmyō taìi [Summary of Inmyō]. Kyoto: Hōzōkan.

Bun'yū Nanjō 


\section{Secondary Sources}

Asō, Yoshiteru Kinsei Nihon tetsugaku shi: Bakumatsu kara Meiji ishin no keimō shisō

1942 [History of Philosophy in Modern Japan: Enlightenment Thought from the End of the Edo Period to the Meiji Period]. Reprint (2008), Tokyo: Shoshi shinsui.

Jorgensen, John "Indra’s Network: Zhang Taiyan's Sino-Japanese Personal Networks 2014 and the Rise of Yogācāra in Modern China.” In Transforming Consciousness: Yogācāra Thought in Modern China, ed. J. Makeham, 64-99. New York: Oxford University Press.

Klautau, Orion Kindai Nihon shisō toshite no Bukkyō shigaku [Buddhist History as

2012 Modern Japanese Thought]. Kyoto: Hōzōkan.

Lai, Yujing "Bakumatsu-ki ni okeru 'kangen' to 'kengen' / 'kenpaku': 'Genro 2013 tōkai' wo megutte ['Kangen,' 'Kengen,' and 'Kenpaku' at the End of the Edo Period: Concerning 'Genro dōkai'].” Kotoba to bunka [Issues in Language and Culture] 14.

Mohr, Michel "Murakami Senshō: In Search of the Fundamental Unity of 2005 Buddhism”. The Eastern Buddhist, New Series 37(1-2).

Moro, Shigeki "Kira Kōyō’s Inmyō Interpretations and Western Logic.” Journal of

2015a Indian and Buddhist Studies 63(3).

2015b Ronri to rekishi: Higashi ajia bukkyo ronrigaku no keisei to tenkai [Logic and History: Formation and Expansion of Buddhist Logic in East Asia], Kyoto: Nakanishiya shuppan.

Sakaguchi, Mitsuhiro "1880 nendai bukkyō-kei no han-kirisutokyō undo" [Buddhist 1989a Anti-Christian Movements in the 1880s: the Spread of AntiChristian Works, and the Activities of Lecture Associations/ Meetings]. Haiya-ron no kenkyü [Studies of Anti-Christian Movements in Japan]. Tokyo: Kyōbunkan.

1989b "Bakumatsu ishinki no haiyaron" [On the Anti-Christian Movement in the Meiji Restoration Period]. Kirisutokyō shakaimondai kenkyü [The Study Committee of Christianity \& Social Problems of the Institute for the Study of Humanities \& Social Sciences, Doshisha University] 37.

Sato, Atsushi "Inoue Enryo and the Thought of Yoshitani Kakuju." International

2015 Inoue Enryo Research 3. 
Shields, James Mark "Parameters of Reform and Unification in Modern Japanese 2005 Buddhist Thought: Murakami Senshō and Critical Buddhism.” The Eastern Buddhist, New Series 37(1-2).

Thelle, Notto R. Buddhism and Christianity in Japan: From Conflict to Dialogue, 1987 1854-1899. Honolulu: University of Hawaii Press.

Tokushige Asakichi, Meiji Bukkyō zenshū [Collection of Buddhist Books in the Meiji ed. 1935 era], vol. 8. Tokyō: Shun'yōdō.

Ward, Ryan "Against Buddhist Unity: Murakami Senshō and his Sectarian 2005 Critics." The Eastern Buddhist, New Series 37(1-2). 